\title{
PREFERENCES OF CARABID BEETLES (COLEOPTERA: CARABIDAE) FOR HERBACEOUS SEEDS
}

\author{
Pavel Saska ${ }^{1}$, Alois HoněK ${ }^{2}$ and Zdenka Martinková ${ }^{3}$ \\ Crop Research Institute, Functional Biodiversity Group \\ Drnovská 507, Praha 6 - Ruzyně, 16106, Czech Republic, \\ ${ }^{1}$ E-mail: saska@vurv.cz; https://orcid.org/0000-0003-1397-2987 \\ ${ }^{2}$ E-mail: honek@vurv.cz; https://orcid.org/0000-0002-0460-4798 \\ ${ }^{3}$ E-mail: martinkova@vurv.cz; https://orcid.org/0000-0003-3402-9242
}

Preferences of seed predators may be an important factor that introduces bias in the results of seed predation studies. In this paper, we report on the experimentally established preferences of carabid beetles for seeds of herbaceous plants. The standard arrangement of 28 species of seeds from 13 families was offered to 37 species of carabids belonging to 5 tribes. The overall consumption was affected by the body mass more than by the body length and showed a quadratic relationship with the dry body mass of the carabid. The number of preferred species of seeds varied from 1 to 16, and in unspecialized species the ordered standardized consumptions formed an almost straight line with negative slope, while in specialized to highly specialized species the standardized consumption exponentially declined with increasing order of species. The most preferred seeds were Taraxacum officinale, Capsella bursa-pastoris, Tripleurospermum inodorum and Descurainia sophia, which were preferred by 28, 20, 19 and 19 species of carabids, respectively, while Consolida regalis, Arctia lappa and Bidens tripartita were not preferred by any of the studied carabids. We pinpoint that choice for a model seed species for a seed predation experiment in the field shall reflect the attractiveness of the seed for predators as seed identity may bring bias in the results.

Keywords: ground beetles, seed predation, granivory, food web, ecosystem service.

\section{INTRODUCTION}

Seed predation is ecosystem service the importance of which is rapidly gaining reputation among ecosystem network ecologists, agro-ecologists and plant population ecologists (e.g. Westerman et al. 2003b, KulKarni et al. 2015, Blubaugh et al. 2016, Larios et al. 2017, Petit et al. 2017), but the road to adoption and utilization of this service in practical weed control in arable systems is still very long to go. One reason why including seed predation as a standard instrument in the weed management toolbox remains difficult is that it is highly variable and unpredictable in time and space (WESTERMAN et al. 2003b, Saska et al. 2008, Petit et al. 2011, Kulkarni et al. 2015).

The literature showed cases when seed predators consumed up to 53$95 \%$ of the annual production of seeds of the studied weed species (HARRISON et al. 2003, Westerman et al. 2003b, Honek et al. 2005, Westerman et al. 2011, DAvis et al. 2013). Other studies have indicated that predation of $25-50 \%$ of 
annually produced seeds might slow down or stop the growth of a population of a weed (Firbank \& Watkinson 1986, Westerman et al. 2005), which suggests that seed predators might be capable of managing the weed populations through reducing the input of seeds in the seed bank, which has been proven experimentally on a national scale (BoHAN et al. 2011). Less optimistic results are provided by studies in which the observed seed predation was very low (BARAIBAR et al. 2012) or was temporally or spatially unrelated to densities of seed predators in the study fields (SASKA et al. 2008). One might expect that density-dependence would occur between the intensity of seed predation and populations of seed predators (BoHAn et al. 2011), but apparently there are many confounding factors at various scales that modulate this relationship (Fox et al. 2013, van Der LaAt et al. 2015, Diekotter et al. 2016, Pетіт et al. 2017) and make the predictions of the impact of seed predation on weed populations in particular field difficult, if not impossible.

We assume that composition of the community of seed predators represent a substantial source of blur in seed predation studies not because of the species identity per se, but more importantly because of the ecological functional traits through which particular species enter the food webs of arable fields. Besides vertebrates, such as birds and rodents, and other invertebrates, such as ants, crickets, terrestrial isopods and slugs, carabid beetles (Coleoptera: Carabidae) often represent the dominant component of the seed predation guild in arable fields of temperate climatic zone (WESTERMAN et al. 2003a, HoneK et al. 2005, Gaines \& Gratton 2010, Bohan et al. 2011, Baraibar et al. 2012, VAN DER LAAT et al. 2015). Carabid beetles are enormously diverse not only in species numbers, but also in their trophic specializations, which range from rather strict specialist carnivores (e.g. Loricera pilicornis, genera Notiophilus and Cychrus) through generalist omnivores (e.g. Poecilus cupreus, Pterostichus melanarius) to obligatory (e.g. genus Amara) and strict granivores (e.g. genus Ophonus) (Brandmayr Zetto \& Brandmayr 1975, Thiele 1977, HengeVeld 1980, Hurka 1996, SAska 2008a, Talarico et al. 2016). Various authors use different classifications of carabids according to their diet (e.g. HомвuRG et al. 2014, Hodecé et al. 2016, Magura \& Lövei 2017, Nolte et al. 2017, Petit et al. 2017, Pizzolotтo et al. 2018) when attempting to assess the functional community composition. Unfortunately, the dietary breadth of many species is poorly known, so the species are often classified differently across studies, which results in the fact that species are commonly placed in different trophic groups by particular authors. More information shall therefore be gained on carabid food, including seed, preferences in order to understand better the trophic position of the common carabid species of arable fields (KULKarni et al. 2015), which would make the predictions of the impact of a carabid beetlesbased seed predator community on weed seed populations in arable fields more trustworthy. 
In this paper, we provide experimentally established seed preferences for 37 species of carabid beetles occurring in arable fields in Europe, and in this way, we contribute to better understanding of the food ecology of these species.

\section{MATERIAL AND METHODS}

\section{Carabid beetles}

Seed preferences were estimated for adults of 37 species of carabid beetles (Table 1) belonging to the tribes Zabrini (18 species), Harpalini (15 spp.), Pterostichini (1 sp.), Platynini (2 spp.) and Trechini ( $1 \mathrm{sp}$.). All species are locally and temporarily common in cultivated land (fields and their margins, gardens, orchards, fallow fields, etc.). Their average body length ranged from ca 4 to $16 \mathrm{~mm}$ (Hurka 1996), based on which the average dry body mass was calculated using the formula of JАRоšíк (1989). The beetles were collected in Prague-Ruzyně (Czech Republic), Štúrovo (Slovakia), Moča (Slovakia), Wageningen (The Netherlands) and Vienna (Austria) (Table 1), by pitfall trapping or hand collecting by Pavel Saska and/or Alois Honěk. After collecting the beetles were stored in 0.5 litre plastic bottles filled with folded moist filter paper and transported to the laboratory. Individuals from outside the Czech Republic were sent (delivery time $<4$ days) in plastic bottles (100 $\mathrm{ml}$ ) filled with a mixture of moist filter paper and sand. In the laboratory, the adults were stored for $3-5$ days in the dark at temperatures of $5-7^{\circ} \mathrm{C}$. This cold storage prevented cannibalism and standardised the level of hunger. The beetles were then removed from the cold, randomly assigned into groups of 10 and immediately used in preference experiments. They were not sexed.

\section{Seeds}

Preference essays were based on seeds of 28 species of dicotyledoneous herbaceous species belonging to 13 families (Table 2, Киви́т 2002). All species are growing on arable land, in ruderal habitats and along field and woody margins so the seeds may be encountered by the species of carabids used in the experiment. The selection of seed species was deliberate to cover a range of seed weights from 0.1 to $8.7 \mathrm{mg}$ evenly. The seeds were collected in 1999-2000 at several localities within $30 \mathrm{~km}$ of Prague. The seeds were dried under room conditions $\left(25-28^{\circ} \mathrm{C}, 40 \%\right.$ r.h.) for 3-4 weeks, then stored frozen until used in the preference experiments. Seed mass (Table 2) of each batch of seed was determined by weighing 100 air dried seeds on Sartorius balances to a precision of $10^{-5} \mathrm{~g}$.

\section{Preference experiments}

The preference experiments were conducted from April to October, 2001-2013 (Table $1)$. The seeds were exposed to carabid predation in small tin trays $(28 \mathrm{~mm}$ in diameter, surface area $6.2 \mathrm{~cm}^{2}, 6 \mathrm{~mm}$ deep, Honek et al. 2003, 2007, SAska et al. 2014a). The trays were filled with white modelling clay (Plasticina JOVI ${ }^{\circledR}$, Barcelona, Spain) and the seeds were pressed into the modelling clay to half their transverse width so they could be easily picked up by the beetles. The number of seeds per tray was 15 for large or 30 for small seeds (Table 2). Preference experiments took place in Petri dishes (250 $\mathrm{mm}$ in diameter, $50 \mathrm{~mm}$ deep), 


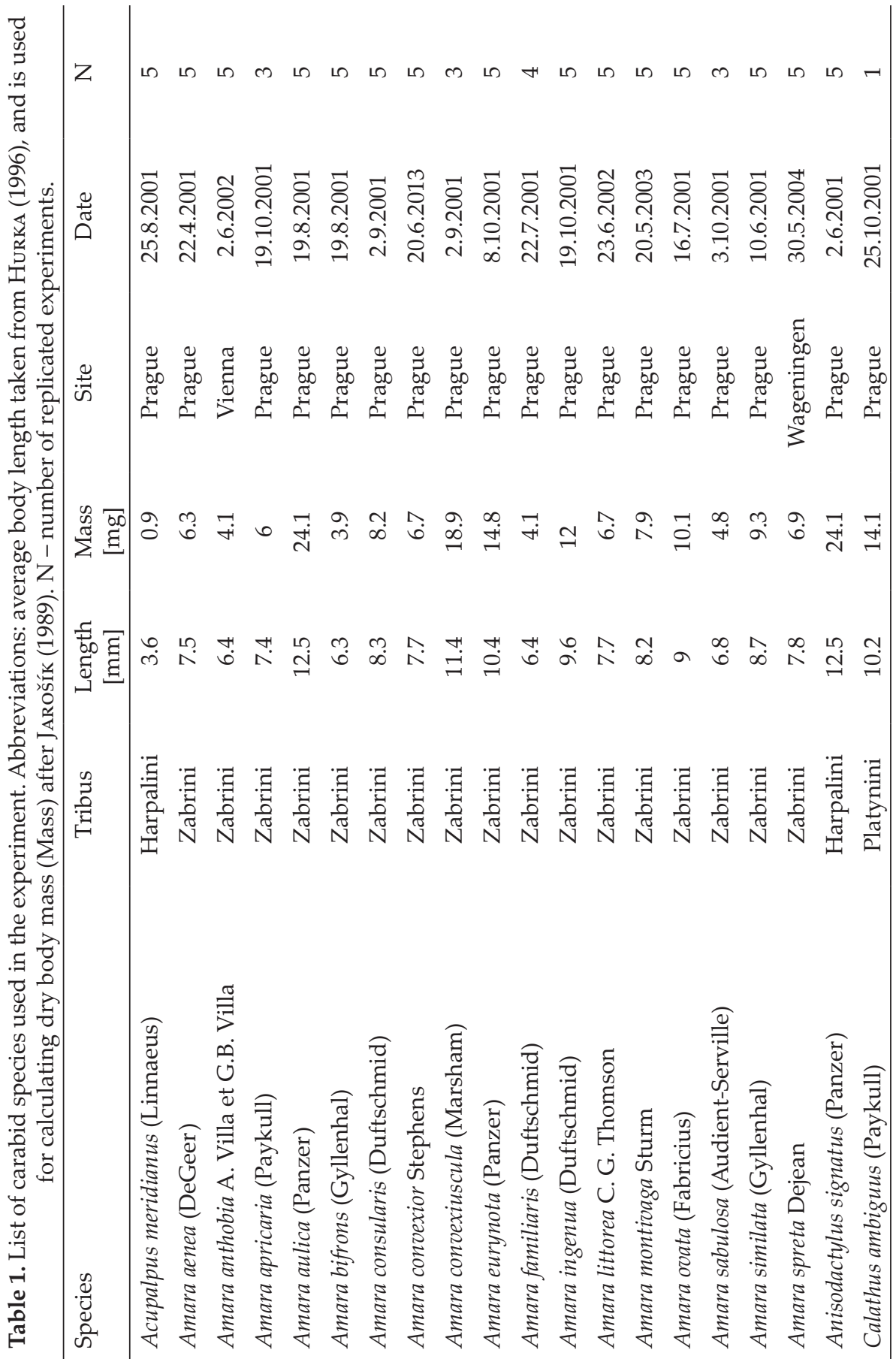




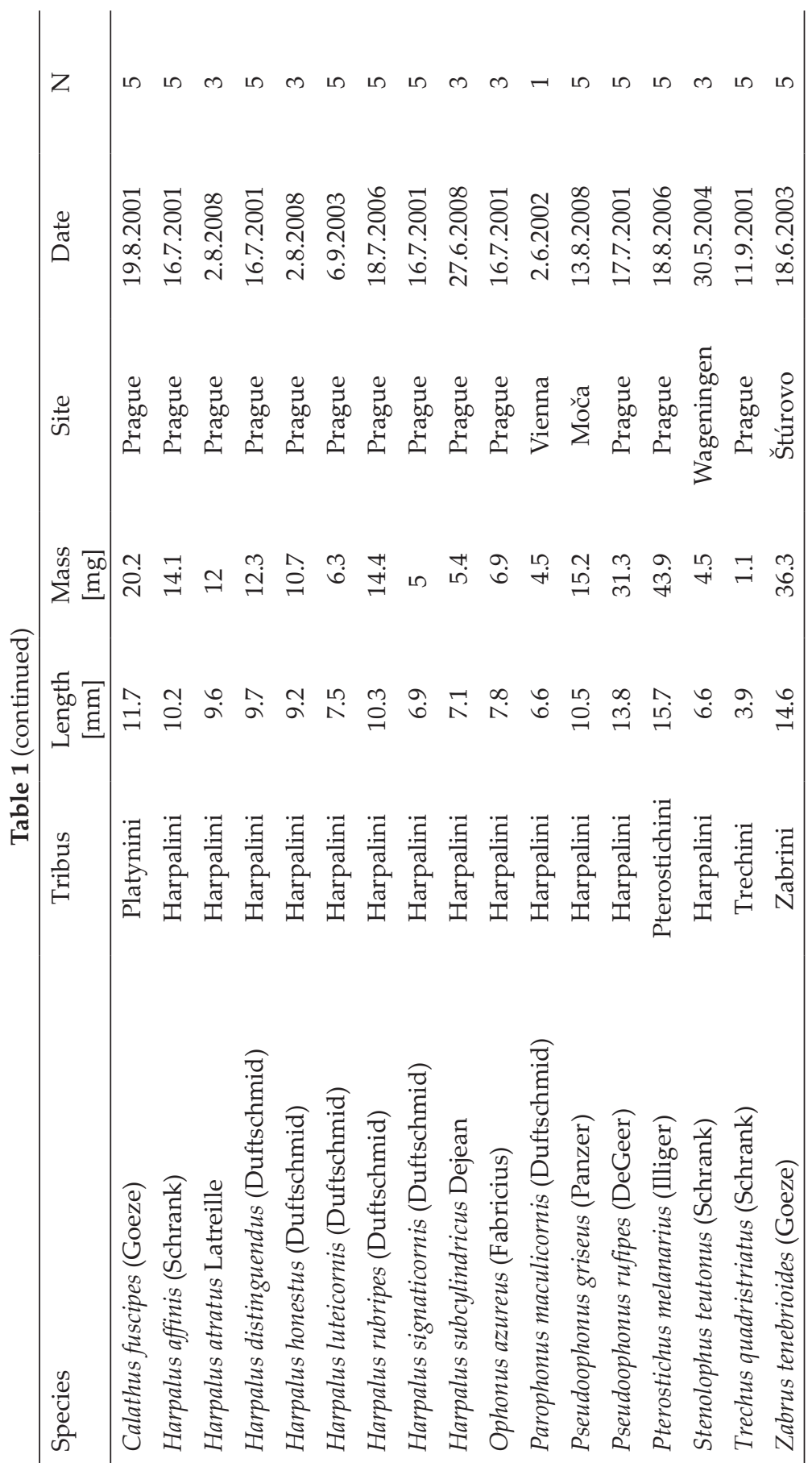


each containing a $1 \mathrm{~cm}$ layer of sieved soil (mesh diameter $4 \mathrm{~mm}$ ) which did not contain any seeds from the soil bank. The trays were pressed to the soil so that the clay surface was flush with that of the soil. The trays were arranged in a standard order (Table 1) and exposed in two concentric circles - the outer circle consisted of 19 trays at c. $0.5 \mathrm{~cm}$ inter-

Table 2. List of seed species used in the experiment. Order indicates the arrangement of particular species -1-19 were in the outer circle and 20-28 in the inner circle.

\begin{tabular}{|c|c|c|c|c|}
\hline Species & Family & Mass [mg] & Order & $\begin{array}{l}\mathrm{N} \text { seeds } \\
\text { per tray }\end{array}$ \\
\hline Amaranthus retroflexus L. & Amaranthaceae & 0.53 & 17 & 30 \\
\hline Arctium lappa L. & Asteraceae & 8.72 & 16 & 15 \\
\hline Arenaria serpyllifolia agg. & Caryophyllaceae & 0.05 & 7 & 30 \\
\hline Bidens tripartita L. & Asteraceae & 2.69 & 22 & 15 \\
\hline Campanula trachelium L. & Campanulaceae & 0.18 & 2 & 30 \\
\hline Capsella bursa-pastoris (L.) Med. & Brassicaceae & 0.23 & 15 & 30 \\
\hline Chenopodium album L. & Amaranthaceae & 0.70 & 27 & 30 \\
\hline Cichorium intybus L. & Asteraceae & 1.09 & 26 & 30 \\
\hline Cirsium arvense (L.) Scop. & Asteraceae & 0.79 & 11 & 30 \\
\hline Consolida regalis S.F.Gray & Ranunculaceae & 1.38 & 21 & 15 \\
\hline Crepis biennis L & Asteraceae & 0.67 & 1 & 30 \\
\hline Descurainia sophia (L.) Prantl & Brassicaceae & 0.11 & 3 & 30 \\
\hline Fumaria officinalis L. & Fumariaceae & 3.01 & 25 & 15 \\
\hline Galinsoga parviflora Cav. & Asteraceae & 0.17 & 5 & 30 \\
\hline Galium aparine L. & Rubiaceae & 6.64 & 10 & 15 \\
\hline Lapsana communis L. & Asteraceae & 1.38 & 20 & 30 \\
\hline Leonurus cardiaca L. & Lamiaceae & 0.64 & 13 & 30 \\
\hline Lepidium ruderale L. & Brassicaceae & 0.21 & 8 & 30 \\
\hline Melilotus albus Med. & Fabaceae & 1.81 & 24 & 30 \\
\hline Potentilla argentea L. & Rosaceae & 0.08 & 6 & 30 \\
\hline $\begin{array}{l}\text { Silene latifolia ssp. alba (Mill.) } \\
\text { Greuter et Burdet }\end{array}$ & Caryophyllaceae & 0.79 & 19 & 30 \\
\hline Sisymbrium loeselii L. & Brassicaceae & 0.08 & 28 & 30 \\
\hline Stellaria media (L.) Vill. & Caryophyllaceae & 0.42 & 14 & 30 \\
\hline Taraxacum officinale agg. & Asteraceae & 0.48 & 18 & 30 \\
\hline Thlaspi arvense L. & Brassicaceae & 0.97 & 9 & 30 \\
\hline $\begin{array}{l}\text { Tripleurospermum inodorum (L.) } \\
\text { Schultz-Bip. }\end{array}$ & Asteraceae & 0.32 & 4 & 30 \\
\hline Urtica dioica $\mathrm{L}$. & Urticaceae & 0.14 & 23 & 30 \\
\hline Viola arvensis Murray & Violaceae & 0.46 & 12 & 30 \\
\hline
\end{tabular}


vals, while the inner circle consisted of 9 trays, similarly spaced. The circles were separated by c. $2.5 \mathrm{~cm}$ of bare ground. Before introducing the beetles, the soil in each Petri dish was moistened with $50 \mathrm{ml}$ of tap water and a piece of moist cotton wool provided a source of water for the beetles. For most species, this experiment was replicated five times (5 Petri dishes with ten beetles in each), except for less common species for which there were fewer replicates (Table 1). The experiments were done in a room in which the temperature fluctuated between $25-27^{\circ} \mathrm{C}$, relative humidity in the Petri dishes was $100 \%$ and the natural photoperiod increased from $14.5 \mathrm{~h}$ light (day length plus civil twilight) : $9.5 \mathrm{~h}$ dark (April 14) to $17 \mathrm{~h}$ light : $7 \mathrm{~h}$ dark (June 23 ), then decreased to $11 \mathrm{~h}$ light : $13 \mathrm{~h}$ dark (Oct. 30). Each run continued for five days and the numbers of remaining seeds per tray were recorded daily. Missing seeds and those of which $>50 \%$ was consumed were considered eaten. The trays were replaced if $>50 \%$ of the seed was removed. The total number of seeds consumed per tray was summed over the 5-day period.

\section{Data analysis}

The following expressions of seed consumption were used:

The total seed consumption ( $\mathrm{T}_{\mathrm{S}}$ ) is the mean number of all seeds consumed by a species over the experimental period.

The mean individual consumption $\left(\mathrm{I}_{\mathrm{S}}\right)$ is $\mathrm{T}_{\mathrm{S}}$ divided by the number of individuals and duration of the experiment, so it expresses the number of seeds eaten by an individual per day.

The total mass consumption $\left(\mathrm{T}_{\mathrm{M}}\right)$ is the mean seed mass consumed by a carabid species over the experimental period.

The mean individual mass consumption $\left(\mathrm{I}_{\mathrm{M}}\right)$ is $\mathrm{T}_{\mathrm{M}}$ divided by the number of individuals and duration of the experiment, so it expresses the seed mass eaten by an individual per day.

Specific consumption $\left(\mathrm{C}_{\mathrm{S}}\right)$ is $\mathrm{I}_{\mathrm{M}}$ divided by the dry body mass of a particular carabid species.

For each carabid species, a standardized consumption was also calculated so for each seed species the actual seed consumption was expressed as the proportion of maximum consumption by the carabid species in seed numbers. From this each species of seed was assigned as "preferred" $(\mathrm{P})$ when the standardized consumption was at least 0.2 of the maximum consumption, "consumed" $(\mathrm{C})$ when the standardized consumption was between 0.2 and 0.05 of the maximum consumption, and "rejected" (R) when the standardized consumption was below 0.05 of the maximum consumption. The threshold of 0.2 between $\mathrm{P}$ and $\mathrm{C}$ species was chosen post hoc based on the visualization of the ranked preferences as the around this value the line of ordered standardized preferences often broke. The threshold of 0.05 distinguishing $C$ and $R$ species was chosen arbitrarily as standardized consumption below this value represented randomly picked seeds.

Linear and quadratic regression (PEKÁr \& BRABEC 2009) were used to test the relationships between the consumption variables and carabid dry body mass and body length in $R$ 3.3.3 (R Development Team 2017).

\section{RESULTS}

Overall consumption and preferences greatly varied among species of carabids. The $\mathrm{T}_{\mathrm{S}}$ ranged from ca 34 to 1272 seeds over the experimental pe- 
Table 3. Seed consumption by 37 carabid species and their dietary breadth. $\mathrm{T}_{\mathrm{S}}-$ total seed consumption [ $\mathrm{N}$ seeds]; $\mathrm{I}_{S}$ - mean individual consumption $\left[\mathrm{N}\right.$ seeds ind ${ }^{-1}$ day $\left.^{-1}\right] ; \mathrm{T}_{\mathrm{M}}$ - total mass consumption [mg seeds]; $\mathrm{I}_{\mathrm{M}}-$ mean individual mass consumption [mg seeds ind $^{-1}$ day $^{-1}$ ]; $\mathrm{C}_{\mathrm{S}}$ - specific consumption [mg seeds ind ${ }^{-1}$ day $^{-1} \mathrm{mg}$ beetle ${ }^{-1}$. $\mathrm{P}$ - number of preferred species; $\mathrm{C}$ - number of consumed species; $\mathrm{R}$ - number of rejected species.

\begin{tabular}{|c|c|c|c|c|c|c|c|c|}
\hline \multirow{2}{*}{ Species } & \multirow{2}{*}{$\mathrm{T}_{\mathrm{s}}$} & \multirow{2}{*}{$\mathrm{I}_{\mathrm{S}}$} & \multirow{2}{*}{$\mathrm{T}_{\mathrm{M}}$} & \multirow{2}{*}{$\mathrm{I}_{\mathrm{M}}$} & \multirow{2}{*}{$\mathrm{C}_{\mathrm{s}}$} & \multicolumn{3}{|c|}{ Preference } \\
\hline & & & & & & $\mathrm{P}$ & $\mathrm{C}$ & $\mathrm{R}$ \\
\hline A. meridianus & 46.0 & 0.92 & 8.11 & 0.162 & 0.180 & 6 & 3 & 19 \\
\hline A. aenea & 706.8 & 14.14 & 204.49 & 4.090 & 0.654 & 9 & 3 & 16 \\
\hline A. anthobia & 408.8 & 8.18 & 133.58 & 2.672 & 0.649 & 5 & 3 & 20 \\
\hline A. apricaria & 129.3 & 2.59 & 71.26 & 1.425 & 0.236 & 3 & 5 & 20 \\
\hline A. aulica & 329.6 & 6.59 & 407.88 & 8.158 & 0.339 & 2 & 10 & 16 \\
\hline A. bifrons & 154.4 & 3.09 & 59.49 & 1.190 & 0.301 & 1 & 5 & 22 \\
\hline A. consularis & 140.6 & 2.81 & 74.58 & 1.492 & 0.183 & 5 & 8 & 15 \\
\hline A. convexior & 387.4 & 7.75 & 111.85 & 2.237 & 0.334 & 8 & 7 & 13 \\
\hline A. convexiuscula & 923.7 & 18.47 & 530.78 & 10.616 & 0.562 & 11 & 12 & 5 \\
\hline A. eurynota & 902.6 & 18.05 & 386.34 & 7.727 & 0.521 & 12 & 8 & 8 \\
\hline A. familiaris & 485.3 & 9.71 & 166.01 & 3.320 & 0.807 & 6 & 5 & 17 \\
\hline A. ingenua & 484.4 & 9.69 & 282.56 & 5.651 & 0.471 & 8 & 8 & 12 \\
\hline A. littorea & 910.6 & 18.21 & 332.61 & 6.652 & 0.992 & 9 & 5 & 14 \\
\hline A. montivaga & 326.6 & 6.53 & 189.42 & 3.788 & 0.479 & 2 & 1 & 25 \\
\hline A. ovata & 825.6 & 16.51 & 347.08 & 6.942 & 0.686 & 9 & 4 & 15 \\
\hline A. sabulosa & 181.0 & 3.62 & 64.13 & 1.283 & 0.266 & 3 & 5 & 20 \\
\hline A. similata & 1221.4 & 24.43 & 391.20 & 7.824 & 0.846 & 12 & 2 & 14 \\
\hline A. spreta & 657.8 & 13.16 & 202.43 & 4.049 & 0.584 & 8 & 4 & 16 \\
\hline A. signatus & 1271.8 & 25.44 & 789.04 & 15.781 & 0.655 & 16 & 8 & 4 \\
\hline C. ambiguus & 70.0 & 1.40 & 38.08 & 0.762 & 0.054 & 3 & 2 & 23 \\
\hline C. fuscipes & 49.0 & 0.98 & 18.65 & 0.373 & 0.018 & 10 & 6 & 12 \\
\hline H. affinis & 694.2 & 13.88 & 419.57 & 8.391 & 0.596 & 13 & 10 & 5 \\
\hline H. atratus & 801.0 & 16.02 & 513.67 & 10.273 & 0.856 & 8 & 12 & 8 \\
\hline H. distinguendus & 1004.6 & 20.09 & 498.72 & 9.974 & 0.811 & 15 & 6 & 7 \\
\hline H. honestus & 653.7 & 13.07 & 313.38 & 6.268 & 0.586 & 11 & 8 & 9 \\
\hline H. luteicornis & 342.0 & 6.84 & 158.94 & 3.179 & 0.508 & 8 & 13 & 7 \\
\hline H. rubripes & 507.2 & 10.14 & 418.08 & 8.362 & 0.581 & 9 & 11 & 8 \\
\hline H. signaticornis & 418.0 & 8.36 & 152.71 & 3.054 & 0.609 & 6 & 13 & 9 \\
\hline H. subcylindricus & 493.7 & 9.87 & 131.20 & 2.624 & 0.486 & 10 & 6 & 12 \\
\hline O. azureus & 72.3 & 1.45 & 169.73 & 3.395 & 0.489 & 5 & 6 & 17 \\
\hline P. maculicornis & 369.0 & 7.38 & 83.69 & 1.674 & 0.375 & 6 & 6 & 16 \\
\hline
\end{tabular}


Table 3 (continued)

\begin{tabular}{lrrrrrrrrr}
\hline \multirow{2}{*}{ Species } & \multirow{2}{*}{$\mathrm{T}_{\mathrm{S}}$} & \multirow{2}{*}{$\mathrm{I}_{\mathrm{S}}$} & $\mathrm{T}_{\mathrm{M}}$ & $\mathrm{I}_{\mathrm{M}}$ & $\mathrm{C}_{\mathrm{S}}$ & \multicolumn{2}{c}{ Preference } \\
\cline { 7 - 11 } & & & & & & $\mathrm{P}$ & $\mathrm{C}$ & $\mathrm{R}$ \\
\hline P. griseus & 1228.6 & 24.57 & 570.25 & 11.405 & 0.750 & 14 & 6 & 8 \\
P. rufipes & 778.0 & 15.56 & 578.91 & 11.578 & 0.370 & 9 & 12 & 7 \\
S. teutonus & 90.2 & 1.80 & 70.77 & 1.415 & 0.032 & 4 & 9 & 15 \\
T. quadristriatus & 365.3 & 7.31 & 74.46 & 1.489 & 0.334 & 9 & 3 & 16 \\
Z.tenebrioides & 34.2 & 0.68 & 5.64 & 0.113 & 0.101 & 3 & 3 & 22 \\
Mean & 466.6 & 9.33 & 350.56 & 7.011 & 0.193 & 5 & 5 & 18 \\
\hline
\end{tabular}
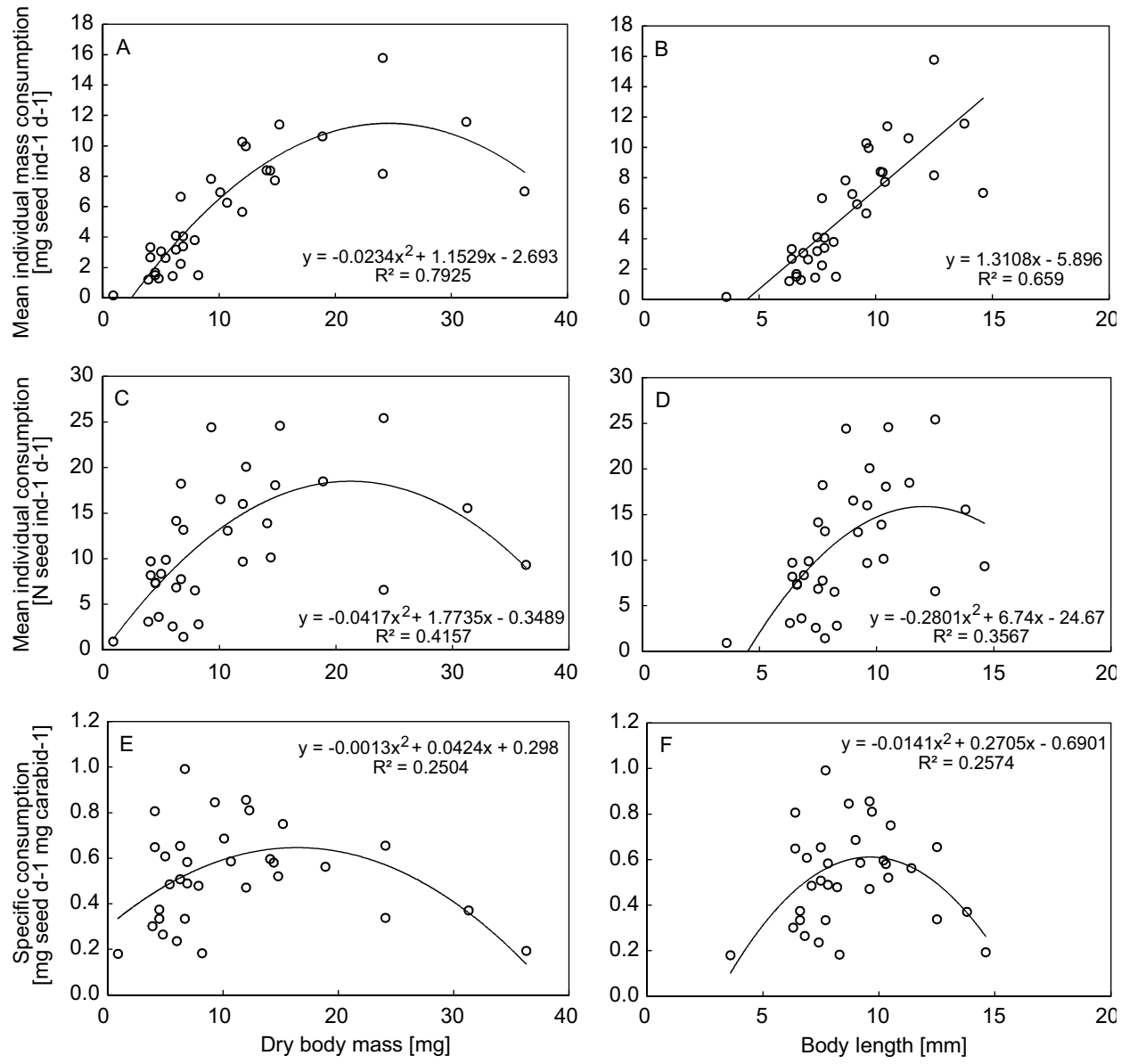

Fig. 1. Variation in seed consumption with carabid dry body mass (A, C, E) and body length (B, D, F). Seed consumption expressed as mean individual mass consumption (A, $\mathrm{B})$, mean individual consumption $(\mathrm{C}, \mathrm{D})$ and specific consumption $(\mathrm{E}, \mathrm{F})$ 


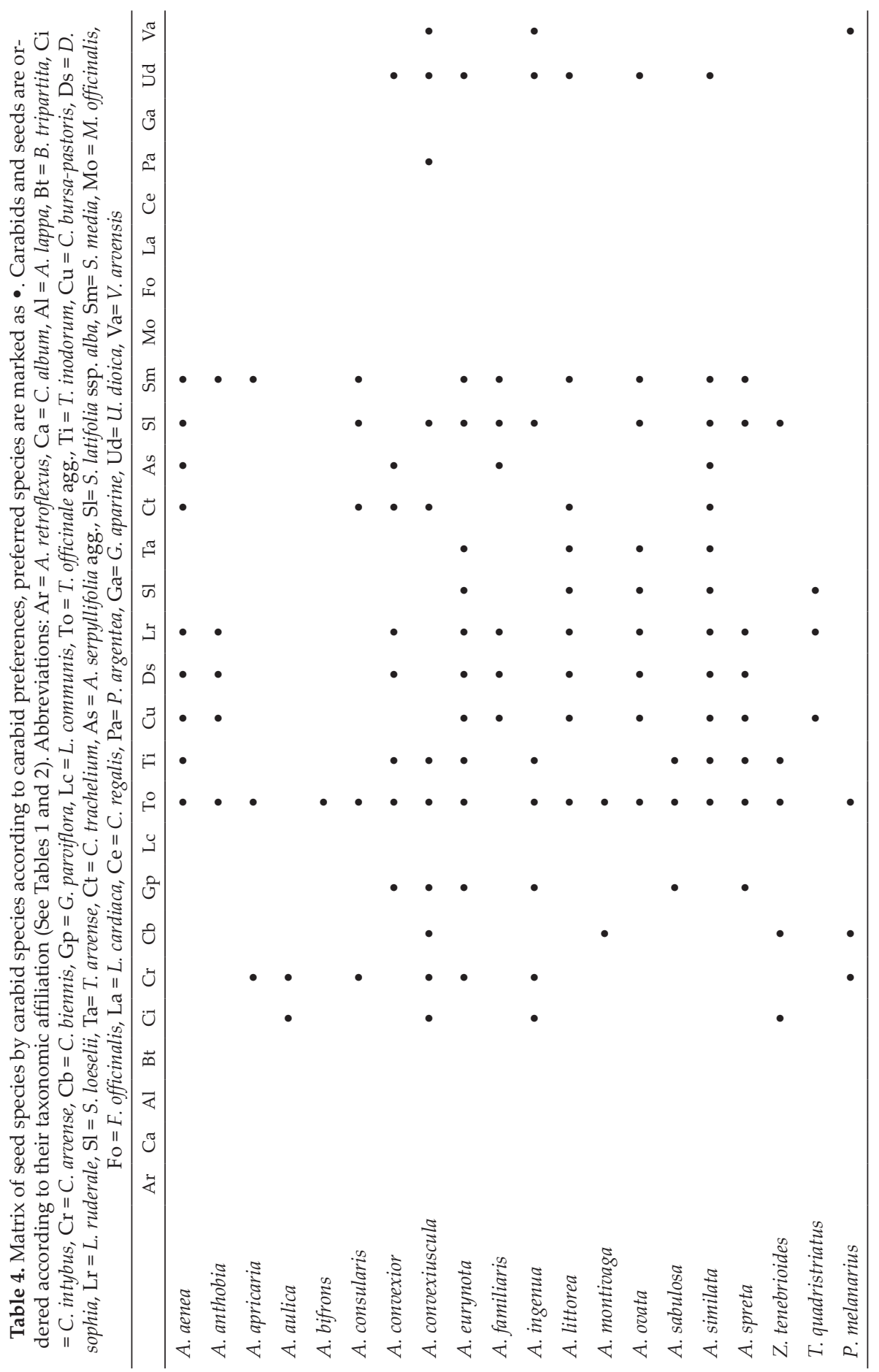




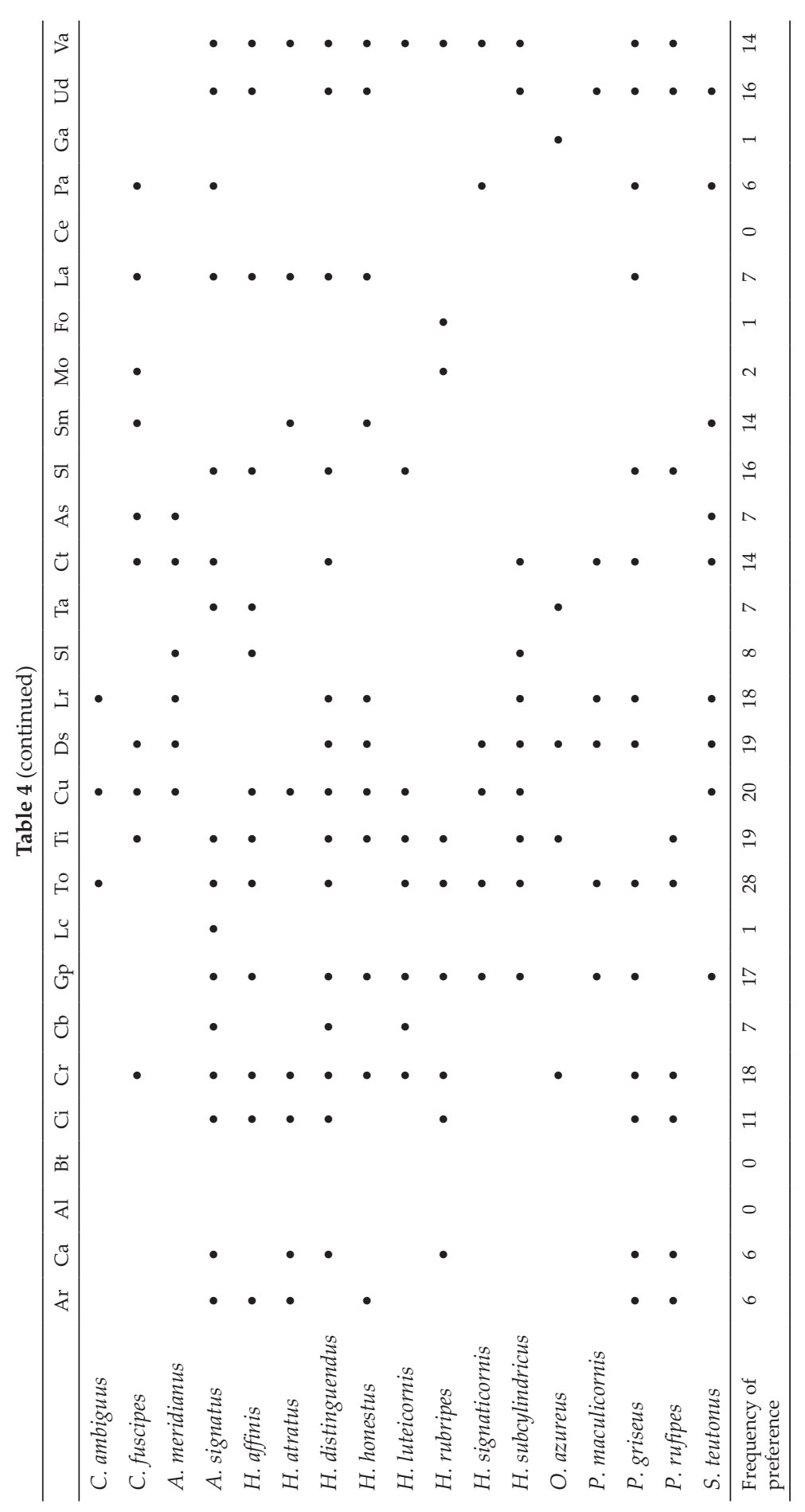


riod, which is equivalent to less than 1 and more than 24 seeds per individual and day (Table 3). The $T_{M}$ of particular species varied from 6 to $789 \mathrm{mg}$ seeds over the experimental period, which is equivalent to the range of ca 0.1 to almost $16 \mathrm{mg}$ seeds per individual and day (Table 3 ). $\mathrm{C}_{\mathrm{S}}$ varied from ca 0.02 to $0.99 \mathrm{mg}$ of seeds per day and $\mathrm{mg}$ of dry mass of the carabid (Table 3 ).

Consumption was affected by the body size, while body mass seemed to be a better predictor of the consumption than body length (Fig. 1). Also, species not belonging to the tribes Harpalini or Zabrini tended to eat seeds of the offered species only reluctantly (Table 3 ), so these were excluded from further analyses. $\mathrm{I}_{\mathrm{M}}$ showed a strong quadratic relationship with dry body mass of the carabid (Fig. 1a) with a maximum consumption achieved by carabids that were around $25 \mathrm{mg}$ of carabid dry body mass, and positive linear relationship with body length (Fig. $1 b$ ). The quadratic relationship between the $\mathrm{I}_{\mathrm{S}}$ and dry body mass was also significant but less strong (Fig. 1c) or weak in the case body length (Fig. 1d), and between $\mathrm{C}_{\mathrm{S}}$ and dry body mass or body length it was still significant but very week (Figs 1e, f).

The preferences and their breadths also varied with carabid species (Tables $3 \& 4$ ). The number of preferred species of seeds varied from 1 to 16 (Tables 3 \& 4). In species which were unspecialized (i.e. preferred many species of seeds) the standardized consumptions were organized along an almost straight line with negative slope, while in specialized to highly specialized
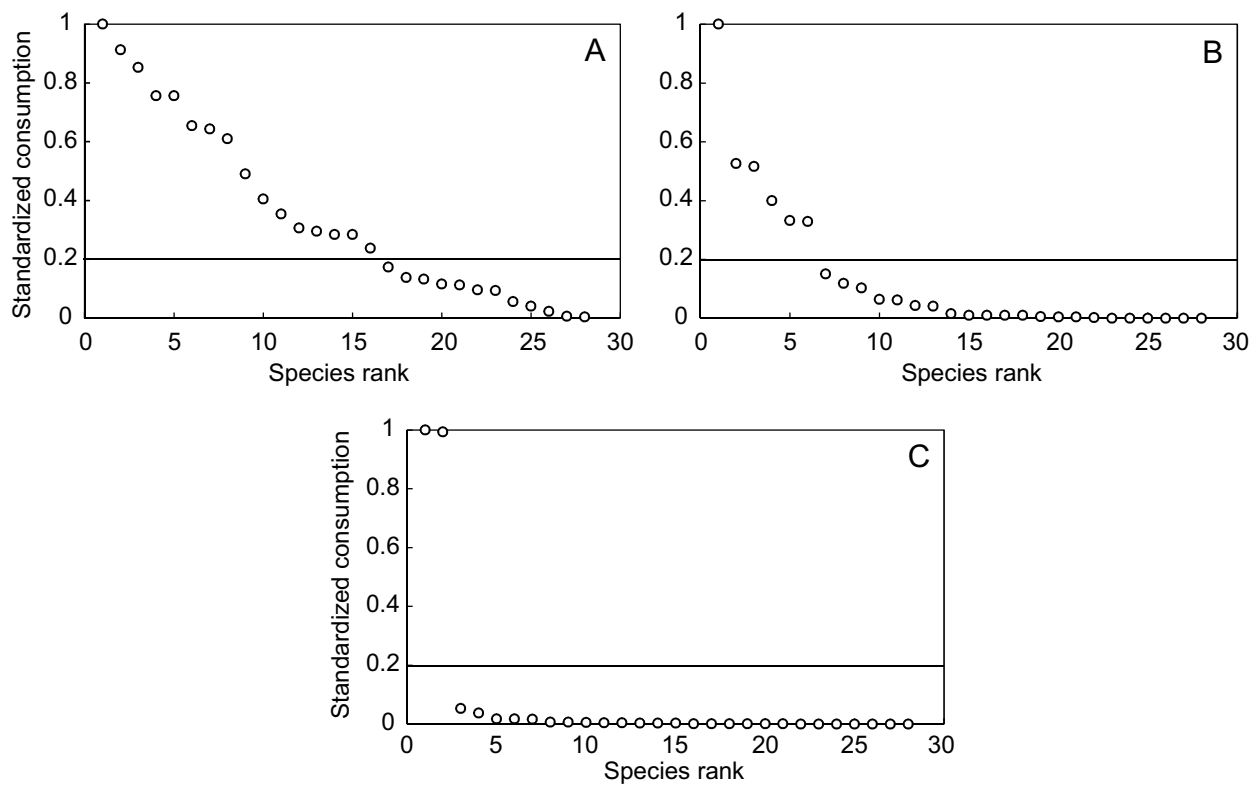

Fig. 2. Ranked standardized consumption of seeds. (A) Anisodactylus binotatus; (B) Amara familiaris; (C) Amara montivaga 

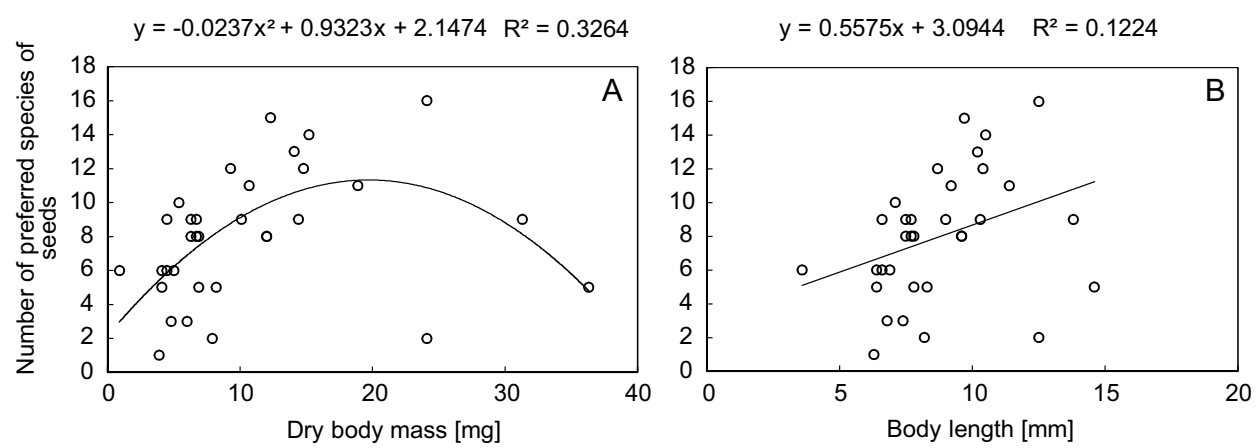

Fig. 3. Variation in the breadth of preferences with dry body mass (A) and body length (B)

species (i.e. those that preferred only a few species of seeds) the standardized consumption exponentially declined with increasing order of species (Fig. 2). The breadth of preference for seed seemed to show a quadratic pattern with dry body mass and a linear one with body length (Fig. 3), but the relationships were rather week. On the other hand, the breadth of preferences was strongly positively related to the $\mathrm{I}_{\mathrm{S}}$ (Fig. $4 a$ ) and less strongly but still significantly so with $\mathrm{I}_{\mathrm{M}}$ and $\mathrm{C}_{\mathrm{S}}$ (Figs $\left.4 b, c\right)$.
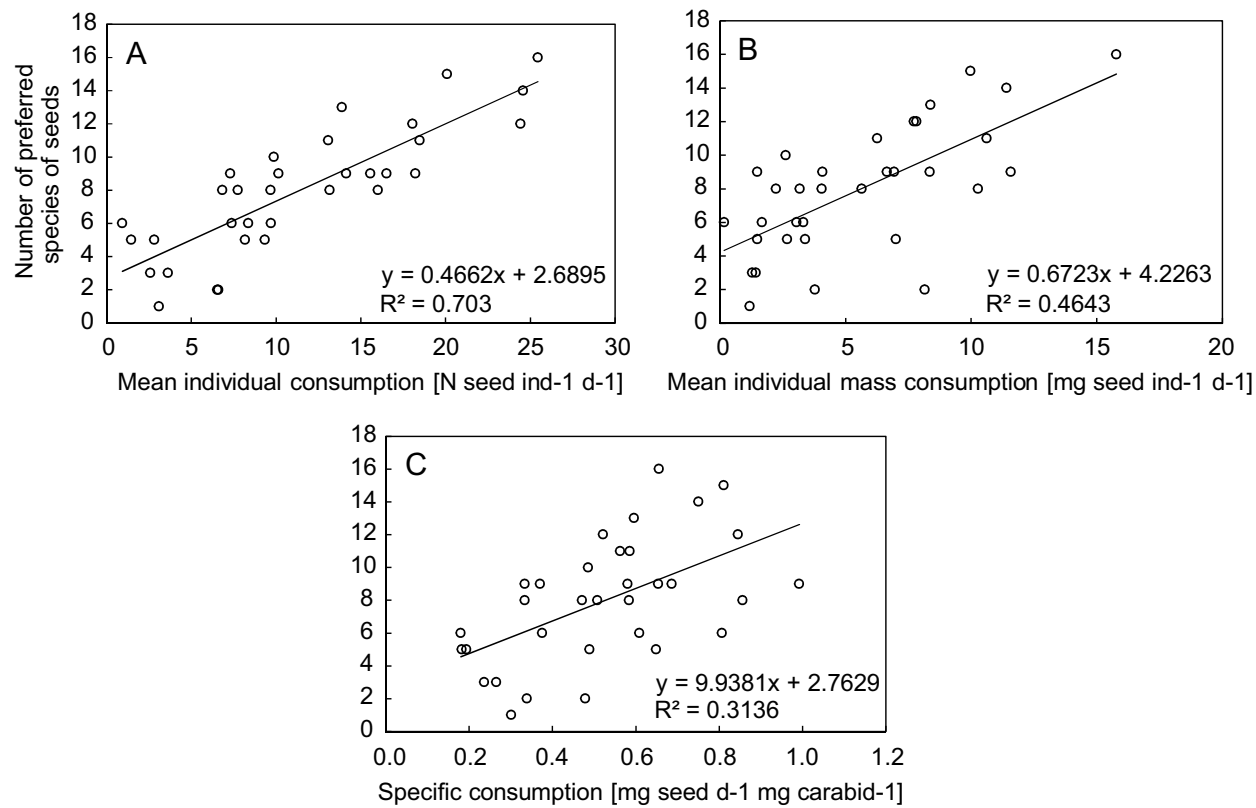

Fig. 4. Variation in the breadth of preferences with consumption. (A) Mean individual consumption; (B) mean individual mass consumption; (C) specific consumption 
Also, particular seed species differed in their attractiveness for carabid beetles as the frequency of being preferred largely varied among the species of seeds (Table 4). The most preferred ones were T. officinale, C. bursa-pastoris, T. inodorum and D. sophia, which were preferred by $28,20,19$ and 19 species of carabids, respectively, while $C$. regalis, $A$. lappa and $B$. tripartita were the most rejected as they were not preferred by any of the studied carabid, followed by G. aparine, F. officinalis and L. communis, each being preferred by only one species of carabids (Table 4 ).

\section{DISCUSSION}

We show in this paper that seed consumption, seed preferences and the breadths of seed preferences differ among the species of carabids and that these differences were observed in groups that are generally regarded as granivorous or at least in which seeds constitute an important part of their diet (Zabrini and Harpalini).

Seed consumption varied with the body size of the beetles and the observed patterns were analogous to what was previously described in the literature (HoneK et al. 2007). We demonstrated quadratic relationships for consumption and body size metrics, i.e. dry body mass and body length, except for the combination of body length and $\mathrm{I}_{\mathrm{M}^{\prime}}$ which however may be an artefact of missing data for carabids longer than $15 \mathrm{~mm}$ in our study. Body length was in general worse predictor of consumption patterns than dry body mass, possibly because body mass reflects better the need for energy intake of an individual. The existence of such quadratic relationships indicates that small and large species of carabids ate fewer seeds compared to the intermediate ones at both absolute and relative (to body size) scale. One might ask why this was the case. We think that the answer to this question can be deduced from the fact that also the number of preferred species, i.e. the breadth of preferences, showed the same pattern. In other words, smaller and larger species of carabids not only ate fewer seeds but also preferred fewer species of seeds compared to middle-sized ones. We think that this relates to the size ratio of the carabid species with the seeds offered in this study. Hence small carabids on average preferred smaller seed species which they were capable to grasp and crush, and large species preferred larger seed species as they were incapable to hold smaller seeds in their mouthparts. On the contrary, middle-sized species are able to utilize not only the species of seeds intermediate in size but also small and larger ones, which has resulted in overall higher consumption and lower specificity for species of seeds.

Another reason why less specialized species of carabids consumed overall larger amounts of seeds might relate to the fact that they could be less 
efficient in obtaining nutrients from the food they eat than more specialized species (Dethier 1954, Slansky \& Scriber 1985) so they are predestined to eat a variety of foods and in larger amounts to meet their energy requirements (WALdBAuer \& Friedman 1991).

In this study the preferences of individual species were estimated based on the multi-choice, or cafeteria, experiment, which is a frequently used approach (Honek et al. 2003, 2007, SASKA et al. 2014a). This kind of experiments basically provide relative preferences as the choice for a seed may be influenced by the presence of another seed species (Charalabidis et al. 2017). We believe that this is not a problem for estimating the real preferences that occur in the field as the seeds of species that were heavily eaten in this study were regularly replenished so they were presented in excess during the entire experiment. The only problem might arise in the case when the seed species included in the array would not be those that carabids normally come across in the field, or if by chance a preferred species would not be included. The species of seeds included in this study can be frequently encountered by most of the species of carabids, but as the seed selection was made a priori, it is possible that some of the seeds important for carabids were neglected. On purpose we did not include seeds of the families Poaceae and Apiaceae, which are known to be preferred by the species of the subgenus Zezea (genus Amara, Hurka 1996) and genus Ophonus (Brandmayr Zetto \& Brandmayr 1975), respectively, but do not stick well in the modelling clay we used to carry the seeds (SASKa et al. 2014a, A. HonĚK, unpublished observation). The other approach of determining preferences includes the no-choice experiment, i.e. providing just one species of seeds at a time. In this way, the willingness to accept, or chose, the seed would provide a measure of preference for particular seed (Charalabidis et al. 2017). However, such a design, despite providing some benefits (ChARAlabidis et al. 2017), represents simplified situation from the field conditions when more species of seeds, or types of prey in general, are available at a time at the scale of the daily radius of movement by an individual.

The preferences were measured under a situation of presenting the seeds to 10 conspecific individuals at the same time. Potentially the risk of intraspecific competition might affect the consumption at individual level, however the recent paper of CHARALABIDis et al. (2017) has shown on the example of $H$. affinis, a species that is also included in this study, and under no-choice situation, that intraspecific competition was not perceived as a risk in terms of the number of seeds eaten. If intraspecific competition may affect the actual preference is not known, but given that many species have the preference clearly determined, we assume it has only a minor effect if any.

Preferences varied among the species of carabids notably. The species of Harpalini were generally less selective and preferred more species of seeds 
than the species of Zabrini (Honek et al. 2007), but we cannot discriminate the taxonomic effect from the size effect as the species of Harpalini included in the study were on average larger than those of Zabrini. But, some affinities to seeds can be observed at the level of carabid tribes, such as that several Harpalini exclusively preferred both species of Amaranthaceae and L. cardiaca. In Zabrini, some differences can also be observed among spring and autumn reproducing species. Besides a pool of species commonly preferred at the genus level, the autumn reproducing species Amara preferred seeds of $C$. intybus and C. arvense, while the spring breeding species preferred seeds of Brassicaceae. This may relate to the period of seed shed (Кивát 2002) and carabid phenology - species reproducing in spring predominantly preferred seeds of plants that are massively shed in spring and early summer, while those reproducing in autumn seemed to prefer seeds that are available in autumn. The notable exception in this study is represented by A. eurynota, which belonged to the most generalist species of the genus and preferred species of seeds typical for spring and autumn species of Amara. The reason can be found in the fact that it is the only known winter breeding species of the subgenus Amara, which starts reproducing in late autumn (SASKA 2004, SASKA et al. 2014b) and continues laying eggs over winter if conditions are suitable, until very early spring (Bílý 1972).

There are several close interactions observed in this study for which literature support exists. In this study, A. aulica preferred only two species of seeds, both of Asteraceae, which is in line with the field observation of adult feeding and laboratory tests made on larvae (SASKa 2005). Similarly, A. montivaga preferred another two species of Asteraceae in this as well as in another studies (HoneK et al. 2005, SASKa 2015). Other trophic links are suggested by the data, i.e. preference of O. azureus for seeds of G. aparine.

In this study, we contributed to understanding the food preferences of an array of arable field inhabiting carabid species. Besides the notoriously known tribes of seed-eating carabids, Zabrini and Harpalini, we also included species of other genera. Although the seed consumption by these species was not overwhelming, they may occasionally eat seeds also in the field and in some circumstances, they may appear to be important granivores (KopRDova et al. 2008, SASKA 2008b). The inconstant attractiveness of seeds to carabid beetles shall be considered when planning the seed predation studies in the field as choosing the "wrong" seed may obscure the results. We recommend T. officinalis, C. arvense, T. inodorum and C. bursa-pastoris as promising model species of weeds for such studies due to the fact they are preferred by a wide range of carabid species.

Besides the seed properties studied in this study (seed mass) and mentioned above (phenological match), other seed traits might be responsible for 
such a variable attractiveness of seeds to carabids. These may include variability in e.g. nutritional content, mechanical or chemical protection, or stimulating cues elicited from the seeds. These factors are investigated in ongoing research.

Acknowledgements - We are grateful to Ludmila Kreslová and Jana Kohoutová for technical assistance. The work was supported by the Czech Science Foundation, grant \#17$00043 S$ (P.S.) and by the Ministry of Agriculture of the Czech Republic, institutional support MZE-RO0418 (A.H. and Z.M.).

\section{REFERENCES}

Baraibar, B., Daedlow, D., De Mol, F. \& Gerowitt, B. (2012): Density dependence of weed seed predation by invertebrates and vertebrates in winter wheat. - Weed Research 52: 79-87. https://doi.org/10.1111/j.1365-3180.2011.00889.x

Bílý, S. (1972): Larva of Amara (Amara) eurynota (Panzer) (Coleoptera, Carabidae) and notes on bionomy of this species. - Acta Entomologica Bohemoslovaca 69: 324-329.

Blubaugh, C. K., Hagler, J. R., Machtley, S. A. \& Kaplan, I. (2016): Cover crops increase foraging activity of omnivorous predators in seed patches and facilitate weed biological control. - Agriculture Ecosystems \& Environment 231: 264-270. https://doi. org/10.1016/j.agee.2016.06.045

Bohan, D. A., Boursault, A., Brooks, D. R. \& Petit, S. (2011): National-scale regulation of the weed seedbank by carabid predators. - Journal of Applied Ecology 48: 888-898. https://doi.org/10.1111/j.1365-2664.2011.02008.x

Brandmayr Zetto, T. \& Brandmayr, P. (1975): Biologia di Ophonus puncticeps Steph. Cenni sull fitofagia delle larve e loro etologia (Coleoptera, Carabidae). - Annali delle Facolta di Scienze Agrarie della Universita degli Studi di Torino 9: 421-430.

Charalabidis, A., Dechaume-Moncharmont, F. X., Petit, S. \& Bohan, D. A. (2017): Risk of predation makes foragers less choosy about their food. - PLoS ONE 12. https://doi. org/10.1371/journal.pone.0187167

Davis, A. S., Taylor, E. C., Haramoto, E. R. \& Renner (2013): Annual postdispersal weed seed predation in contrasting field environments. - Weed Science 61: 296-302. https:// doi.org/10.1614/WS-D-12-00157.1

Dethier, V. G. (1954): Evolution of feeding preferences in phytophagous insects. - Evolution 8: 33-54. https://doi.org/10.2307/2405664

Diekotter, T., Wamser, S., Dorner, T., Wolters, V. \& Birkhofer, K. (2016): Organic farming affects the potential of a granivorous carabid beetle to control arable weeds at local and landscape scales. - Agricultural and Forest Entomology 18: 167-173. https:// doi.org/10.1111/afe.12150

Firbank, L. G. \& Watkinson, A. R. (1986): Modeling the population-dynamics of an arable weed and its effects upon crop yield. - Journal of Applied Ecology 23: 147-159. https:// doi.org/10.2307/2403088

Fox, A. F., Reberg-Horton, S. C., Orr, D. B., Moorman, C. E. \& Frank, S. D. (2013): Crop and field border effects on weed seed predation in the southeastern US coastal plain. - Agriculture Ecosystems \& Environment 177: 58-62. https://doi.org/10.1016/j. agee.2013.06.006 
Gaines, H. R. \& Gratton, C. (2010): Seed predation increases with ground beetle diversity in a Wisconsin (USA) potato agroecosystem. - Agriculture Ecosystems \& Environment 137: 329-336. https://doi.org/10.1016/j.agee.2010.03.003

Harrison, S. K., Regnier, E. E. \& Schmoll, J. T. (2003): Postdispersal predation of giant ragweed (Ambrosia trifida) seed in no-tillage corn. - Weed Science 51: 955-964. https:// doi.org/10.1614/P2002-110

Hengeveld, R. (1980): Polyphagy, oligophagy and food specialization in ground beetles (Coleoptera, Carabidae). - Netherlands Journal of Zoology 30: 564-584. https://doi. org/10.1163/002829679X00197

Hodecek, J., Kuras, T., Sipos, J. \& Dolny, A. (2016): Role of reclamation in the formation of functional structure of beetle communities: A different approach to restoration. - Ecological Engineering 94: 537-544. https://doi.org/10.1016/j.ecoleng.2016.06.027

Homburg, K., Homburg, N., Schafer, F., Schuldt, A. \& Assmann, T. (2014): Carabids. org - a dynamic online database of ground beetle species traits (Coleoptera, Carabidae). - Insect Conservation and Diversity 7: 195-205. https://doi.org/10.1111/icad.12045

Honek, A., Martinkova, Z. \& Jarošík, V. (2003): Ground beetles (Carabidae) as seed predators. - European Journal of Entomology 100: 531-544. https://doi.org/10.14411/ eje.2003.081

Honek, A., Martinkova, Z. \& SAska, P. (2005): Post-dispersal predation of Taraxacum officinale (dandelion) seed. - Journal of Ecology 93: 345-352. https://doi.org/10.1111/ j.1365-2745.2005.00987.x

Honek, A., Martinkova, Z., Saska, P. \& Pekar, S. (2007): Size and taxonomic constraints determine the seed preferences of Carabidae (Coleoptera). - Basic and Applied Ecology 8: 343-353. https://doi.org/10.1016/j.baae.2006.07.002

Hurka, K. (1996): Carabidae of the Czech and Slovak Republics. Carabidae České a Slovenské republiky. - Kabourek, Zlín, 565 pp.

JARošík, V. (1989): Mass vs. length relationship for carabid beetles (Col., Carabidae). - Pedobiologia 33: 87-90.

Koprdova, S., SASKa, P. \& Soukup, J. (2008): The spectrum of invertebrate seed predators that contribute to the control of the rape volunteer seeds (Brassica napus L.). - Journal of Plant Diseases and Protection 21(Special issue): 261-264.

Kuвát, K. (2002): [The Key to the Flora of the Czech Republic]. - Academia, Praha, 927 pp.

Kulkarni, S. S., Dosdall, L. M. \& Willenborg, C. J. (2015): The role of ground beetles (Coleoptera: Carabidae) in weed seed consumption: A review. - Weed Science 63: 355-376. https://doi.org/10.1614/WS-D-14-00067.1

Larios, L., Pearson, D. E. \& Maron, J. L. (2017). Incorporating the effects of generalist seed predators into plant community theory. - Functional Ecology 31: 1856-1867. https:// doi.org/10.1111/1365-2435.12905

Magura, T. \& LöveI, G. (2017): Environmental filtering is the main assembly rule of ground beetles in the forest and its edge but not in the adjacent grassland. - Insect Science 26(1): 154-163. https://doi.org/10.1111/1744-7917.12504

Nolte, D., Schuldt, A., Gossner, M. M., Ulrich, W. \& Assmann, T. (2017): Functional traits drive ground beetle community structures in Central European forests: Implications for conservation. - Biological Conservation 213: 5-12. https://doi.org/10.1016/j. biocon.2017.06.038

Pekár, S. \& Brabec, M. (2009): [Modern analysis of statistical data 1]. - Sciencia, Mnisek pod Brdy, 226 pp. 
Petit, S., Boursault, A., Le Guilloux, M., Munier-Jolain, N. \& Reboud, X. (2011): Weeds in agricultural landscapes. A review. - Agronomy for Sustainable Development 31: 309_ 317. https://doi.org/10.1051/agro/2010020

Petit, S., Trichard, A., Biju-Duval, L., Mclaughlin, O. B. \& Bohan, D. A. (2017): Interactions between conservation agricultural practice and landscape composition promote weed seed predation by invertebrates. - Agriculture Ecosystems \& Environment 240: 45-53. https://doi.org/10.1016/j.agee.2017.02.014

Pizzolotto, R., Mazzei, A., Bonacci, T., Scalercio, S., Iannotta, N., Brandmayr, P. (2018): Ground beetles in Mediterranean olive agroecosystems: Their significance and functional role as bioindicators (Coleoptera, Carabidae). - PLoS ONE 13. https://doi. org/10.1371/journal.pone.0194551

SASKA, P. (2004): Carabid larvae as predators of weed seeds: granivory in larvae of Amara eurynota (Coleoptera: Carabidae). - Communications in Agricultural and Applied Biological Sciences 69: 27-33.

SASKA, P. (2005): Contrary food requirements of the larvae of two Curtonotus (Coleoptera: Carabidae: Amara) species. - Annals of Applied Biology 147: 139-144. https://doi. org/10.1111/j.1744-7348.2005.00016.x

SAska, P. (2008a): Effect of diet on the fecundity of three carabid beetles. Physiological Entomology 33: 188-192. https://doi.org/10.1111/j.1365-3032.2008.00618.x

SASKA, P. (2008b): Temporal dynamics of seed predation upon shed seeds of oilseed rape (Brassica napus L.). - Journal of Plant Diseases and Protection 21(Special issue): 199-202.

SASKA, P. (2015): Seed requirements and consumption of Amara montivaga, a granivorous carabid (Coleoptera: Carabidae). - Acta Societatis Zoologicae Bohemicae 71: 121-125.

Saska, P., Koprdova, S., Martinkova, Z. \& HoneK, A. (2014a): Comparing methods of weed seed exposure to predators. - Annals of Applied Biology 164: 301-312. https://doi. org/10.1111/aab.12102

Saska, P., van der Werf, W., de Vries, E. \& Westerman, P. R. (2008): Spatial and temporal patterns of carabid activity-density in cereals do not explain levels of predation on weed seeds. - Bulletin of Entomological Research 98: 169-181. https://doi.org/10.1017/ S0007485307005512

Saska, P., Vlach, M., Schmidtova, J. \& Matalin, A. V. (2014b): Thermal constants of egg development in carabid beetles - variation resulting from using different estimation methods and among geographically distant European populations. - European Journal of Entomology 111: 621-630. https://doi.org/10.14411/eje.2014.077

SlANSKY, F., Jr. \& SCRIBER, J. M. (1985): Food consumption and utilization. Pp. 87-163. In: A. \& GILBERT, L. I. (eds): Comprehensive insect physiology, biochemistry and pharmacology. Pergamon, Oxford.

Talarico, F., Giglio, A., Pizzolotto, R. \& Brandmayr, P. (2016): A synthesis of feeding habits and reproduction rhythm in Italian seed-feeding ground beetles (Coleoptera: Carabidae). - European Journal of Entomology 113: 325-336. https://doi.org/10.14411/ eje.2016.042

R Core TeAm (2017): R: A language and environment for statistical computing. - R Foundation for Statistical Computing, Vienna, Austria. http://www.R-project.org/

Thiele, H. U. (1977): Carabid beetles in their environments. - Springer-Verlag, Berlin, 369 pp. van der LaAt, R., Owen, M. D. K., Liebman, M. \& Leon, R. G. (2015): Postdispersal weed seed predation and invertebrate activity density in three tillage regimes. - Weed Science 63: 828-838. https://doi.org/10.1614/WS-D-15-00030.1 
Waldbauer, G. P. \& Friedman, S. (1991): Self-selection of optimal diets by insects. - Annual Review of Entomology 36: 43-63. https://doi.org/10.1146/annurev.en.36.010191.000355

Westerman, P., Liebman, M., Menalled, F. D., Heggenstaller, A. H., Hartzler, R. G. \& Dixon, P. M. (2005): Are many little hammers effective? - Velvetleaf (Abutilon theophrasti) population dynamics in two- and four-year crop rotation systems. Weed Science 53: 382-392. https://doi.org/10.1614/WS-04-130R

Westerman, P. R., Hofman, A., Vet, L. E. M. \& van der Werf, W. (2003a): Relative importance of vertebrates and invertebrates in epigeaic weed seed predation in organic cereal fields. - Agriculture, Ecosystems and Environment 95: 417-425. https://doi. org/10.1016/S0167-8809(02)00224-4

Westerman, P. R., Luijendijk, C. D., Wevers, J. D. A. \& Van der Werf, W. (2011): Weed seed predation in a phenologically late crop. - Weed Research 51: 157-164. https://doi. org/10.1111/j.1365-3180.2010.00834.x

Westerman, P. R., Wes, J. S., Kropff, M. J. \& van der Werf, W. (2003b): Annual losses of weed seeds due to predation in organic cereal fields. - Journal of Applied Ecology 40: 824-836. https://doi.org/10.1046/j.1365-2664.2003.00850.x

Received January 7, 2019, accepted January 31, 2019, published November 22, 2019 